\title{
Contrapositions between aesthetics and art teaching: the case of "Eredegalda's sad story"
}

\author{
Karla Raphaella Costa Pereiraio \\ Uninassau University Center, Fortaleza, CE, Brazil \\ Frederico Jorge Ferreira Costaiic \\ Ceara State University, Fortaleza, CE, Brazil \\ Ana Paula Sancho Diogo iii(i) \\ Fortaleza City Hall, Fortaleza, CE, Brazil
}

\begin{abstract}
This article results from the analysis of the novel Eredegalda's sad story from the book While sleep does not come, by José Mauro Brant. In 2017, this book was forbidden in the Brazilian public schools for focusing on incest. The controversy gave rise to moral, aesthetic and pedagogical debates. The study is a literary analysis, it was carried out based on the aesthetics of György Lukács and aimed to overcome the duality of moralism-artistic freedom within this debate, pointing out an earlier need: to reflect on the possible pedagogical role of "Eredegalda's sad story". This concrete situation made it possible to move forward in examining the educational character of works of art and the use of literature as a pedagogical instrument. It presents the general situation, then explains the fundamentals on which the investigation was based and, finally, reveals the author's point of view on the work in question.
\end{abstract}

\section{Keywords}

Teaching of art. Teaching of literature. Marxism.

\section{Contraposições entre estética e ensino da arte:}

o caso de "A triste história de Eredegalda"

\begin{abstract}
Resumo
Este artigo resulta da análise do romance "A triste história de Eredegalda", do livro Enquanto o sono não vem, de José Mauro Brant. Em 2017, esse livro foi retirado das escolas públicas brasileiras por tematizar o incesto. A polêmica ensejou debates de base moral, estética e pedagógica. $O$ estudo é uma análise literária, o qual foi realizado com fundamento na estética de György Lukács e teve como objetivo superar a dualidade moralismo - liberdade artística no interior desse debate, apontando uma necessidade anterior: julgar acerca do possível papel pedagógico de "A triste história de Eredegalda". Essa situação concreta possibilitou avançar no exame do caráter educativo das obras de arte e no uso da literatura como instrumento pedagógico. Apresenta-se a situação geral, depois expõem-se os fundamentos sob os quais a investigação se fundou e, por
\end{abstract}


último, revela-se o ponto de vista dos autores sobre a obra em questão, em caráter de ensaio.

Palavras-chave

Ensino da arte. Ensino de literatura. Marxismo.

\title{
Contraposiciones entre estética y enseñanza del arte:
}

\author{
el caso de "La triste historia de Eredegalda"
}

\begin{abstract}
Resumen

\section{Palabras clave}

Enseñanza de arte. Enseñanza de Literatura. Marxismo.
\end{abstract}

Este artículo resulta del análisis de "La triste historia de Eredegalda", del libro Mientras el sueño no viene, de José Mauro Brant. En el año 2017, ese libro fue retirado de las escuelas públicas brasileñas por tematizar el incesto. La polémica planteó debates de base moral, estética y pedagógica. El estudio es un análisis literario. Fue realizado según la estética de György Lukács y tuvo como objetivo superar la dualidad moralismo - libertad artística en el interior de ese debate, apuntando a una necesidad anterior: juzgar acerca del posible papel pedagógico de "La triste historia de Eredegalda". Esta situación concreta posibilitó avanzar en el examen del carácter educativo de las obras de arte y en el uso de la literatura como instrumento pedagógico. Se presenta la situación general, después se exponen los fundamentos bajo los cuales la investigación se fundó y, por último, se revela el punto de vista de los autores sobre la obra en cuestión, en carácter de ensayo.

\section{Introduction}

Literature is not made to teach: it is the reflection on literature that teaches us. (JACINTO DO PRADO COELHO).

This article exposes the results of the analysis of the novel "Eredegalda's sad story" published in the book While sleep does not come, by José Mauro Brant, in the Young Readers collection in 2013. The analysis was carried out in a study group on the Aesthetics of György Lukács (1885 - 1971), a Hungarian Marxist philosopher who, in the last decades of his life, dedicated himself to refounding the ontological bases of Marxism. Linked to graduate education, the group aims to point out the contributions of Lukacsian aesthetics to education, art teaching and teacher training

1 The traditional novel is a poetic-musical composition composed of a series of verses in a larger redondilla with an assonant rhyme. Of medieval origin, it was widely cultivated in the Renaissance. Collected in Cancioneiros, it was transmitted by oral tradition until today.

Educação \& Formação, Fortaleza, v. 5, n. 3, e2996, set./dez. 2020

DOI: https://doi.org/10.25053/redufor.v5i15set/dez.2996

https://revistas.uece.br/index.php/redufor/index 
"Eredegalda's sad story" it is a retelling by Brant himself and based on popular tales. Brant's work was the center of a controversy of national repercussion when it was denounced by teachers of the Elementary School of Vitória (ES) due to the theme of incest. The book was distributed by the Ministry of Education (MEC) as a work selected by the National Literacy Pact at the Right Age (PNAIC/2014), so it had gone through the analysis of the Literacy, Reading and Writing Center (Ceale - FaE/UFMG).

Teachers interviewed in Vitória affirmed that the novel could take children away from reading, because of the theme presented to them who, in literacy, should read fairy tales. It is worth mentioning that the head of the Police Department for Child and Adolescent Protection (DPCA/ES) condemned the work for considering that many children would have had experiences of violence similar to those in history and that reliving them could cause trauma.

The city hall of Vitória, followed by Serra and Cariacica, forwarded the book to the MEC for a pedagogical approval. Ceale - FaE/UFMG prepared an opinion in favor of the work - excerpts from this text will be exposed and analyzed in this article. After this opinion, MEC decided to collect the 93 thousand copies that had been distributed throughout Brazil. The author's reaction was immediate: in one article he claimed the teachers' lack of training to carry out the work, in another he pointed to a moral crisis. According to Brant, in an interview with Ferreira (2017, s.p.):

\begin{abstract}
I did not invented that story. It is a book of stories told in Brazil and like all popular culture content touches on delicate subjects. People have little information about what a fairy tale is. From Little Red Riding Hood to other tales are not banal themes. It is always a message of oppression, of good against evil, "said Brant. That book is 20 years old. The tale has always generated interesting discussions, but nowadays people are very polarized. In such a difficult time, with so much serious topics to discuss, demonizing a story is curious, it is a consequence of our moral crisis.
\end{abstract}

The judgment set out in this article is not based on moral judgment or the universal freedom of the writer. These two antagonistic positions polarized the debate about the novel in question. It is not intended to state whether "Eredegalda's sad story" and the other novels in While sleep does not come are good or bad literary works or whether or not they are high literature. What matters here is the pedagogical role of this work, what is up to these subsequent lines is to know what contribution it can or cannot make to the training of working class individuals. 
In this sense, this study does a literary analysis, exposes a bibliographic study of Lukács' aesthetic work and results in the literary essay now manifested. The text initially presents the outline of the controversy of "Eredegalda's sad story", deepening the information given in this introduction. Then, it highlights the theoretical foundations on which it makes the analysis to, finally, outline an essay on the pedagogical function and the aesthetic function of a work of art and how the case of "Eredegalda's sad story" contributes to the professional development of the teacher of arts and literature in the Brazilian public school.

\section{The outlines of the controversy surrounding "Eredegalda's sad story"}

The novel "Eredegalda's sad story" composes an anthology of recounts from different genres of the popular oral tradition gathered in the work While sleep does not come from the author José Mauro Brant (2013). This work is part of a collection of nine short story books that had its first publication in 2003 by the publisher Rocco, through the label Rocco Jovens Leitores (Rocco Young Readers). Brant studied Languages at the Pontifical Catholic University of Rio de Janeiro (PUC) and, today, he is an actor, singer, storyteller and musical director. This article analyzes only the recounting of "Eredegalda's sad story", due to its negative repercussions.

The author explains, on pages 48 and 49, the context of his narratives so that the reader understands the cultural root of the folk tales on which he based himself to create his short stories:

The novel is a form of popular poetry sung that, in verse, always tells a story. At a time when writing was for very few, music wrote in the memory of troubadours and minstrels the heroic deeds and the tragic stories of imaginary kingdoms. Often they had origins in real events, singers, who were the reporters of the time, took the stories to the squares and halls of medieval Europe. The novels were brought by the Portuguese and Spanish colonizers and still survive today in the memory of the old northeastern novelists. The story of the princess harassed by her own father appears in several places in Brazil with different names: 'Silvaninha', 'Valdomira', 'Faustina'. The version included here was inspired by a collection in Barbacena, Minas Gerais, and was added by the verses of a lullaby called 'There comes an angel'. (BRANT, 2013, p. 48-49).

Educação \& Formação, Fortaleza, v. 5, n. 3, e2996, set./dez. 2020 
The narrative has been part of the traditional oral culture of generations of Brazilians, children and adults, and has echoed in the artistic voices, not only of novelists, but also of young accountants and writers, as is the case of the person who authored the work While the sleep does not come.

The book, which until then went unnoticed on the shelves of bookstores all over Brazil, gained national repercussion by the media thanks to the content of the novel "Eredegalda's sad story", while the other stories that complete the work do not even seem to exist in its content and form, such as: The story of the surrão; The nine daughters; The blind king and the city of Olhos D'Água; The language of birds; João Jiló and two lullabies, Consolation, that starts the work, and Goodbye, goodbye that ends it. "Eredegalda's sad story" is a narrative built on sixteen verses of four verses each, occupies four pages of the book While sleep does not come and the content that drew the critic's attention, as previously said, is the theme of incest.

The plot begins with the exaltation of the beauty of three daughters of a king, being one of incomparable beauty, Eredegalda. Wishing to take possession of her daughter's beauty, the father proposes marriage to her at the expense of making her mother a servant. The young Eredegalda strongly rejects her father's desire and is punished for it. The mother and the two sisters are aware of the king's advances, but do not dare contradict him and deny Eredegalda any help so that she can escape the punishment of eating salty meat without the right to water, trapped in a tower.

\footnotetext{
There were three daughters of a king.

All three were beautiful.

The most beautiful of all

Eredegalda was called

One day his father said to her:

- If you want to marry me,

You will be my wife,

And your mother, our maid.

- Not that, dear father,

It can not be,

I prefer to stay closed

Than to see my mother as a servant.

(BRANT, 2013, p. 27).
}

Educação \& Formação, Fortaleza, v. 5, n. 3, e2996, set./dez. 2020

DOI: https://doi.org/10.25053/redufor.v5i15set/dez.2996

https://revistas.uece.br/index.php/redufor/index 
After begging the mother and sisters for mercy and water, in the face of denial, the princess turns to her father, who is saddened by her refusal, and she promises to accept his proposal. In response, the king sends three knights to the tower, swearing that the first to reach the top with a pitcher of water could marry Eredegalda. Finally, when the three knights arrive at the tower, they found Eredegalda dead, but accompanied by four angels and Jesus.

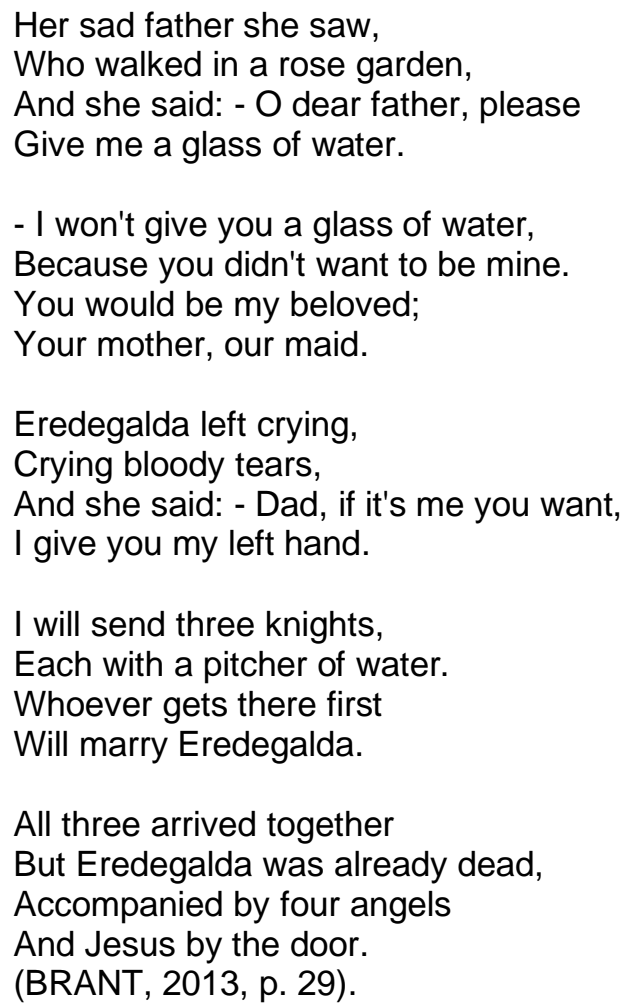

There is a desire on the part of the father and an initial refusal of this desire for the daughter who dies immaculate. The act of incest, which is the reason for all opposition to the work in Brazilian public schools, is not confirmed because the victim refuses, so it is a narrative that themes and condemns incest when presenting the tragedy and sacrifice of Eredegalda.

Brant's book (2013) was selected by the Reading and Writing Literacy Center (Ceale - FaE/UFMG) to compose the collection of the National Literacy Pact at the Right Age 2014 (PNAIC) of the Ministry of Education (MEC). 93 thousand copies of the work were distributed to all public schools in Brazil. The book is aimed at children from six to eight years old in the early years of elementary school, therefore in the process of 
literacy. With this proportion of national reach, the book entered the center of children's literary discussion.

Due to the demonstrations against Brant's work and after the technical opinion issued by the Secretariat of Basic Education (SEB), the MEC decided to collect copies of the book While sleep does not come from all Brazilian public schools because they considered it inappropriate for the public for which it was intended: children aged six to eight years. According to a note from the MEC (2017, s.p.):

\footnotetext{
'Children in the literacy cycle, as readers in training and with limited experience, have not yet acquired autonomy, maturity and critical sense to problematize certain topics with high density, as is the case of the story in question', states the opinion, emphasizing that the text must not only be adapted to the student's linguistic and textual skills, but also to his life experience and the meanings that the work will produce in the reader.
}

It should be noted that the content of Eredegalda's novel was responsible for all this movement in relation to children's literature written by Brant (2013), imposing on Ceale - FaE / UFMG to issue an opinion on the book. In a document, the Center defended the work While sleep does not come and stated that the book thematically reproduces linguistic narrative marks typical of popular tales and that its aesthetic value and editorial quality are suitable for the training of infant readers. It is worth exposing and sometimes reproducing excerpts from this piece, as these notes will be taken up in the next topic of this article.

It was understood, after analysis, that, after the presentation of the work, the opinion of Ceale - FaE/UFMG argues in favor of While sleep does not come and it takes three general dimensions: the nature of literature, the relationship between form and content in the specific Eredegalda's short story and the relationship between literature and the figurative real world. These three dimensions of analysis will be resumed here in order to deepen and substantiate the result of the analysis of this article.

Initially, Ceale's opinion indicates that, despite thematic incest, the narrative does not support it, stating that it is not the theme, but the form of the approach that is considered by the reader in contact with the work. He also argues that themes such as incest, rape, alcoholism, pedophilia, violence, etc., are present in several literary works, including the Bible, and that Brant's version is added by "[...] a lullaby, which serves, then, 
to reinforce the presented plot, highlighting, as already mentioned above, the character's angelic condition" (CEALE, 2017, p. 4).

Furthermore, as already pointed out in its obvious connection with Perrault's Donkey Skin short story, it is a theme that has been present in children's literature for a long time, and should therefore not cause any surprise to teachers who work with the training of children's readers. The timeless way in which the narrative is constructed creates a distance from the present and an immersion in the universe of fiction. It cannot be forgotten that the illustrations, in addition to the text, lead to the universe of fairy tales. Children's literature readers who have already experienced reading experiences with similar narratives enter this universe with this condition: that of fiction readers. (CEALE, 2017, p. 3).

From the point of view of form and its relationship with content, it points out that:

When specifically reading 'Eredegalda's sad story', the following excerpt stands out, at the beginning: 'If you want to marry me, / you will be my wife'. In this passage, it is important to note, in the father's speech, the conditional function exercised by the subordinate conjunction 'if'. The condition of the announced 'marriage' is, however, promptly rejected by the daughter: 'Not that, dear father'. Therefore, denied the possibility of carrying out the alleged incest, the father punishes his daughter ('She could only eat salted meat / without drinking a glass of water'). When trying to ease his punishment, asking his father for water, he, again, acknowledges the denial of his desire ('I won't give you a glass of water, / because you didn't want to be mine.'). The verb tense used, simple past, confirms, once again, the non-occurrence of incest, by concluding the denial that happened in the past. Such denial is further ratified by the father's indignation, represented by the conditional tense: 'You would be my beloved'. Finally, the verses of the lullaby attached to the story finalize the author's free version, confirming Eredegalda's fair conviction, then presented as 'an angel', or rather, 'a virgin' in a veil and wreath. As she was already dead, even her union with the pretending knights indicated by her father is not realized. Thus, we have a popular tale that focuses on incest, but condemning it, by exposing the drama and sacrifice of what could have been its victim. (CEALE, 2017, p. 3, highlights from the original).

It also appropriates the Aristotelian concept of catharsis to defend that, being a:

[...] psychological transference, that is, the reading of a violent scene serves to purge the impulse of violence [...]. Upon seeing them represented in the text, the reader experiences them vicariously, that is, on loan, and thus also gets rid of them. It is because the reader experiences these negative feelings in books, in films, in soap operas that he does not need to bring them into real life. (CEALE, 2017, p. 5).

Based on the above, he argues that literary experience is even more fundamental for children, as they: 
[...] are learning to deal with all these feelings and often they appear contradictory, creating confusion in their heads. That is why the basic material of children's literature, since time immemorial, is precisely composed of the fears, anguish and pain that imply in growing. (CEALE, 2017, p. 5).

According to Ceale - FaE / UFMG, scenes of violence, such as the gutting of the wolf in Little Red Riding Hood, although pleasant to children, would not make them bad pet owners.

\begin{abstract}
On the contrary, scenes like these serve for children to channel and control feelings that are socially repressed at home and at school. By throwing the witch into the pot of boiling water with Hansel and Gretel, for example, the children symbolically experience the feeling of revenge. Putting it in another way, fiction provides the child with a safe environment where he can express and experience feelings that they could not even explain. (CEALE, 2017, p. 5-6, highlight from the authors).
\end{abstract}

Moving towards its conclusion, Ceale states that scenes of violence are part of the stories and that children understand them in this way, therefore:

[...] it is not the scenes of violence present in these and other children's stories that should concern parents and educators, but the gratuity of them as in some narratives that are even less explicit, because this prevents them from exercising the sublimating function that stood out above. (CEALE, 2017, p. 6).

The last selected argument in which the opinion compares the literary experience to the acquisition of antibodies in the natural world follows below:

\begin{abstract}
It is not by denying or hiding the existence of violence in the world that the reader is helped to transform it into a better place to live. Just as children need to play freely on a beach and walk on the sand of the playground even to gain resistance against the bacteria and microbes that live in these environments, they also need to experience and know, albeit symbolically, the dangers and adversities that temper the character. (CEALE, 2017, p. 6).
\end{abstract}

The piece ends by affirming Ceale - FaE/UFMG's indisputable competence in the rigorous selection of works that are destined for schools throughout Brazil and the freedom that Literature cannot do without. After the highlights above, the next topic presents the theoretical bases and considerations about the analyzed work, the criticism suffered by it and the consequent collection of its copies from the national territory. The small historical gap between the case and this analysis allowed for a more detailed study and a deeper reflection that justify the presentation of the conclusions it exposes. The debate, however, is inexhaustible. 


\section{Fundamentals and considerations for an aesthetic criticism: analysis of the "Eredegalda's sad story"}

Initially, it is necessary to establish the theoretical-philosophical foundations on which the analyzes set out below are based: an understanding of Marxist-based aesthetics systematized and disseminated, mainly from the 20th century, by György Lukács and Mikhail Lifshitz, after studies of the manuscripts of Marx filed in the MarxEngels-Lenin Institute in Moscow, in the mid-1930s. The criticism developed here is based on Lukács, fundamentally in his Aesthetics written in the mid-1960s, who is not an author of traditional influence in the field of theory and literary criticism, just as there are few contemporary theorists who, in this field, advocate Marxists.

Marxism, however, influenced several areas of knowledge. It would not be different with art and literature: it collaborated or influenced, in different measures, in the formation of many personalities, such as Raymond Williams, Noam Chomsky, Terry Eagleton, Ernest Ficher, Mikhail Bakhtin, Adolfo Sanchez Vásquez, Fredric Jameson, Adorno, among others; in Brazil, Carlos Nelson Coutinho, Antônio Cândido, Nelson Werneck Sodré, Celso Frederico, Ferreira Gullar, Roberto Schwarz, Jorge Amado, Carlos Drummond de Andrade, Graciliano Ramos, among others. Given this, it is possible to claim the legitimacy of Marxist analyzes in the field of art, literature and culture in general. In the specific case of this study, of Lukácsian tradition.

For the purposes of analyzing the case of the novel "Eredegalda's sad story", it is necessary to clarify the fundamental Lukácsian concepts for understanding the exhibition. They are: everyday life as a soil on which the need for art is born, art as a reflection of an objective and external reality to human beings, aesthetic catharsis as a synthesis of knowledge about human life provided by art and realism as a high form of art. Realism in art is connected with the Marxist method, in as much as objective reality exists before any reflections on it, being more complex than the knowledge that one may have about it (XEREX; COSTA; SANTOS, 2017). 
According to Lukács (1982a), all human objectivations ${ }^{2}$ start from the common ground of everyday life and return to it. In everyday life, human decisions are based on motives of an instantaneous, rigid and fleeting nature, there is an immediate link between theory and practice, because in everyday life, it is necessary that the environment of the human being has a practical purpose. He reacts to the objects in his vicinity in a spontaneously practical way, there is no complete separation between acting and thinking. Daily life is also heterogeneous.

The worker exhausted from a long walk, after an exhausting day of work, upon finding an empty seat on the bus, sits down. No matter how skilled it is to philosophize about the chair, the bus, the conditions of Brazilian public transport, about the law of inertia, about the chair designer, etc., she does not do it, because the chair allows sitting, an action that responds to an immediate need in this woman's daily life. Note that the woman in this symbolic case, has, in her consciousness, at the moment of sitting, reflexes that make this action possible: she knows the function of the chair object, she knows how to travel in a moving bus, she knows that she needs to hold in case the bus stops, etc.

Man and woman immersed in daily life respond to immediate practical needs. In this way, Lukács (1982a) calls the whole man who is immersed in everyday life, as this is oriented to his reality with the entire surface of his existence. When this whole man moves away from everyday life and focuses on an artistic objectification giving in to it the wholeness of his being, Lukács (1982a) calls him a man entirely (homem inteiramente).

In the example above of the worker, a category emerged and it is necessary to explain, according to Lukács (1982a): the reflex. Man experiences the world through experiences and organizes it in consciousness through reflections, images from the outside world. The construction of this reflex in consciousness is mediated by the inseparability between thought and language and its elaboration means an expansion of the domain of reality by man. Here is the caveat: the reflected world is external and independent of human consciousness, however, through the movement of reflection,

2 Objectification is the realization of a subject's previous ideation. It can have a physical materiality like a chair or a social objectivity like value or language.

Educação \& Formação, Fortaleza, v. 5, n. 3, e2996, set./dez. 2020 
the elaboration of concepts, the external world is losing its original immediacy, consequently the human being will be able to act in this world more consciously.

Lukács (1982a) develops concepts about three ways of reflecting reality: the reflection of everyday life as a midpoint and the reflections of science and art in the extremes. It is not within the scope of this text to develop the Lukácsian reflex theory. It is necessary, however, to lead to the characteristics of the artistic reflection of reality: it is anthropomorphizing, it creates a homogeneous world that suspends the human being from the heterogeneity of everyday life, elevates the individual to the typical.

Luckácsian realism defends, based on these and other categories, literary realism as the artist's aesthetic position and commitment. Lukács (2010) states that literature must relate singular facts to general situations, so the events narrated would highlight its exemplary character. In order to be credible and respect the objectivity of reality, a totality needs to appear. In this totality, the characters are typical, that is, they live in their singular lives general problems - it is the figuration of social forms - linking the individual to the universal.

Thus, realism would triumph. "[...] a triumph of the realistic representation, of the literarily accurate and profound reflection of reality, over the individual and class prejudices of the writer" (LUKÁCS, 2010, p. 75). The meaning of the word "realism" can lead to different interpretations. According to Jakobson (2013, p. 110-111), this word has vague content. It can mean the work that the author in question designed as credible, it can mean the work whose judgment of others considers it credible, it can be "[...] the sum of the characteristic features of a traditional 19th century school". Jakobson (2013) warns of the ambiguity possibilities of these definitions. Even taking this risk, here realism is defined, in Lukács' terms, commitment to reflect as closely as possible the totality of reality.

It is possible, after this brief explanation, to enter the exhibition of the pedagogical character of the work of art. Before examining this work, a warning: it is not being stated that art and education as social complexes are identical, but that there is a character, a pedagogical dimension in art, according to Lukács (1982a). It is worth mentioning that "[...] school educational practice is a mediator between the sphere of 
everyday life and the spheres of non-daily life in the process of forming the individual" (MORORÓ, 2017, p. 41).

The world proper to each work of art, alluded to above, is a particular world that has its own laws and does not apply to others. This world does not contradict the reflexive nature of objective reality because, on the one hand, it creates an organic world of its own; on the other hand, it acts in an analogous sense (LUKÁCS, 1978). As human destinations are depicted, the reader identifies with the universality represented in the typical, relating to the work as if it were not a reflection. The function of art is to defitish reality, according to Lukács (1982b).

Art plays the role of self-awareness of human development, of self-perception, of the human being as different from organic nature, because, according to the Magyar philosopher, there is a tendency for earthly immanence, that is, in the aesthetic reflection, the man is always present as a determinant.

The pedagogical-social effectiveness of art, consequently of literature, has as its decisive moment the elevation of the individual from the mere particularity of the subject to the particularity. The reader experiences new experiences, often distant from his daily life, which, while being strange to him as a singular individual, are recognized by him as human, so the individual is enriched in his individuality. If no individual is tabula rasa, the work's effectiveness is also not independent of the recipient, but a synthesis of the work's objective determinations and subjective to the reader, so it cannot be understood as mechanics. "New content comes to him that increases his experiential treasure" (LUKÁCS, 1982b, p. 496).

The catharsis for Lukács (1982b) goes beyond tragedy. For him, catharsis, like all human categories, originates in everyday life; in art, it is a reflection. Catharsis produces a jolt in subjectivity in man, in his pathos, it covers new contents, new directions, that is, through catharsis, made possible in the relationship with a work of art, the human being learns more about himself. The contents are not of the same nature as those obtained by science, they are anthropomorphic contents, with a meaning for themselves, within beings.

Laying the foundations on which the analysis of the novel "Eredegalda's sad story" was carried out, the results of this study are set out below. It was not intended to exhaust the debate, seal the final point or condemn or defend the text, but to 
discuss, in the light of an explicit theoretical framework, the determinations of the novel and the pedagogical function that it, due to its immanent nature, can evoke in the classroom. The central question here is: How "Eredegalda's sad story" contributes to the education of children between six and eight years old in Brazilian public schools?

The highlight above is not free: "children between six and eight years of public schools in Brazil" points to the context in which this work should be developed, indicates a direction for analysis, marks the class, the reality and the needs of these children, stresses that no literary work is read in a vacuum, that no receiver is tabula rasa.

\subsection{Considerations about the specificities of the aesthetic and pedagogical dimensions: an essay on "Eredegalda's sad story"}

The denial of Brant's novel, as can be seen, came about through moral criticism; while the defense made by both Ceale FaE / UFMG and the author themselves aim to defend artistic freedom, the indisputable right of an author to thematize what he wants. The criticism outlined in these lines aims to overcome these two points of view, focusing on the pedagogical character of "Eredegalda's sad story", that is, its use in the classroom as an instrument for teaching.

Educational praxis has a basic specificity, to reproduce creatively, through a series of mediations, in each singular individual a set of skills, knowledge, values, needs and predispositions, previously put forward by each concrete society. According to Saviani (2008), school education is the superior form created by human beings, of production, in individuals, of the attributes that define the highest levels that mankind has historically reached. So, in this perspective, school education has the function of making students take ownership of scientific, artistic and philosophical content, as part of the process, which in a capitalist society is contradictory, of developing more enriched individuals.

Thus, according to Duarte (2016), scientific, artistic and philosophical knowledge carry condensed, synthesized human activity, as latent life. In the pedagogical process, mediated by the teaching praxis, the activity contained in this knowledge becomes a subjective activity of the students and their "second nature" is 
incorporated: in a dialectic between the historical objectification of culture and its appropriation by individuals. In this sense, the content of literature at school is subordinated to this process of developing individualities enriched by the appropriation of the best that was produced by humanity.

The use of literary work in the classroom does not have the same function as access to it outside that space, since when used by the teacher, it is subsumed to the pedagogical sphere. There is a mediation between the work and its constituents - author, form and content - that of the teacher. It should be noted that the receiver is, in addition, a learner. Work and learner are, therefore, in a learning relationship. What was more direct, with circumstantial mediations, work-receiver, starts to be mediated in a premeditated way: work - teacher - receiver/learner.

The mediation of the teacher does not happen accidentally, but her/his class is programmed so that the activities s/he teaches, using the instruments s/he decides to use, lead the student to the appropriation of content. Thus, it is worth asking: what is the pedagogical content of "Eredegalda's sad story"? What elements of reading will be appropriate by the student? What knowledge does this work generate in the student? It is considered here that it is the answers to these questions that make a work feasible or not as pedagogically adequate to the development of certain content for its purpose: the appropriation by the student.

It should be understood that it is no longer about the abstract freedom of the world: an author writes what suits him, a reader reads what interests him, but the teacher uses what is appropriate for teaching, better, for his teaching objectives. In this way, the freedom of the work in the school environment is subordinated to the immanent logic of the educational process. Other elements influence the choice of the teacher: age of students, knowledge about the role of art, literature, chosen works, reading level of students, available works, for example. Thus, even in free reading classes, there is a prior selection of those that best suit these factors.

The result of reading in the classroom and in life is not the same. Aesthetic catharsis cannot be guaranteed, as what mediates it is a series of subjective and objective motives in the work-reader relationship. In the classroom, the teacher can indicate, build the necessary elements for the understanding of a work, but this knowledge does not match in content and form to the aesthetic catharsis. In this way, the 
teaching of literature has a broader function. To highlight it, the words of Leyla PerroneMoisés (2016, p. 80-81) are singular:

\begin{abstract}
Summarizing what was said by the best theorists, we would answer the question 'Why teach studying Literature?', With the following arguments: because teaching literature is teaching to read and, in literate societies, without reading there is no culture; because the ability to read is not innate, but acquired; because literary texts can include all other types of texts that the student must know, to be a citizen able to live in society; because literary texts are those in which the language reaches its highest degree of precision and its greatest power of meaning; because meaning, in the literary text, is not reduced to meaning (as it happens in scientific, journalistic, technical texts), but operates the interaction of several semantic levels and results in a theoretically infinite possibility of interpretations; because literature is an instrument of knowledge of the other and of self-knowledge; because fiction literature, while illuminating reality, shows that other realities are possible, freeing the reader from his narrow context and developing in him the capacity to imagine, which is a human need and can inspire historical transformations; because poetry captures levels of perception and enjoyment of reality that other types of text cannot reach.
\end{abstract}

The author also states: "If we believe in the specific virtues of the literature listed above, we must teach them from the works that have them" (PERRONE-MOISÉS, 2016, p. 81). One wonders: Does "Eredegalda's sad story" have these virtues? If the answer is yes, it is suitable for pedagogical use, although it addresses a subject that is too thorny, such as incest. If the answer to that question is no, the work is dispensable from a pedagogical point of view and its use in the classroom would be harmless.

It was assessed, then, that the analyzed novel does not have these virtues. It is not the literary analysis that justifies this article, but the possibility that the controversy raises: what is up to education in teaching art and, consequently, literature. "Eredegalda's sad story" is an alienated response to an alienated situation. The situation referred to in the previous statement concerns the Brazilian public school today: institutions, except for rare exceptions, precarious and deprived of the function of transmitting the highest that has been produced in human history, in which the teaching activity also emptied by people in strenuous, poorly paid working conditions, without opportunities to expand their training and preparation in the various areas, since they are multitask, etc.

If the theme of incest aimed to elevate students from their daily lives, for example, to learn that the others have no right to the child's body, to report any attempts at abuse, since 40\% of children who suffered sexual abuse between 2015 and 2016 were children 
aged 0 to 11 years, according to MEC (BRASIL, 2017), on the contrary, the narrative of Eredegalda's life, due to the genre, is abstract, that is, it lacks determinations that allow the reader, especially the child, to appropriate the content developed so that their experience is enriched. The popular trova develops an open narrative; the reader fills in what is missing. In the case of children in the literacy phase, it is unlikely that they will have enough experiences and an understanding of these experiences to do so without the narrative being shocked by their own experiences as reality and not as a reflex. A child who suffers or has suffered sexual abuse from their father may be more hurt than overcome the experience that the novel shows.

In addition to what has been said before, Ceale - Fae / UFMG, when arguing the linguistic structure of the text, its verbs in the past, Eredegalda's vehement denial, etc., omits the stanza in which the protagonist gives in to her father's desire and gives him her hand. After seeing her father, she again begs for a glass of water:

\author{
And she said: O dear father, please \\ Give me a glass of water. \\ - I won't give you a glass of water, \\ Because you didn't want to be mine. \\ You would be my beloved; \\ Your mother, our maid. \\ Eredegalda left crying, \\ Crying bloody tears, \\ And she said: - Dad, if it's me you want, \\ I give you my left hand. \\ (BRANT, 2013, p. 29, highlights from the authors).
}

As you can see in the highlights above, Eredegalda was aware of the surrender of herself, of the body to her father's whims and that this surrender would result in marriage. The retelling does not show the age of Eredegalda to give concreteness to the character's knowledge and actions, in this way, the child will have an easier time identifying with the protagonist, including the fact that the characters in the novel are common in wonderful tales, as well as the presented scenario: king, queen, princess, tower. Probably the child relies on memories of this type of genre, hoping for a happy ending, common in wonderful tales and that does not exist in "Eredegalda's sad story" that culminates in a tragedy whose salvation of the character is death and the opportunity for a transcendent life - this issue will not be discussed here. 
By these last elements of a more aesthetic than pedagogical nature, it is understood that the work has no defetishizing effect. It does not have emancipatory elements, in the Lukács sense, it represents an alienated world and does not allow a high understanding of this world, placing the reader in a situation with no way out. The world proper to this work lacks determinations.

Based on what has been said so far, it is worth mentioning that the use of literary works in the classroom is not independent of the role of education, thus the aesthetic form of the work of art can make the pedagogical process unfeasible, as well as the pedagogical process can make the aesthetic appropriation of the work of art unfeasible. It is relevant to think about the role of teacher training for early childhood education, as this teaching stage requires the teacher to master the school content that s/he applies (FONSECA; COLARES; COSTA, 2019). The case of "Eredegalda's sad story" is an example of this.

\section{Final considerations}

Initially, it is worth noting that the competence of Ceale - FaE / UFMG in the analysis and selection of books is not disputed. It is understood here the defense made by the Center in an attempt to keep the work in schools, the questioning concerns the possibility of the "Eredegalda's sad story" exercising a pedagogical function, as well as if as a work it has an educational character. In this sense, these final considerations, three moments referring to this article will be highlighted.

First: the center of the argument is not about literary freedom or about the use of censorship, based on a moralistic and superficial view. Literary freedom, although relative, is unquestionable, that is, it is relative because the authors theorize what interests them, but they do so in the conditions and needs of a historical time and a situated context. What is meant is that Brant's right to treat incest as content and to develop it according to the artistic form he chose is set.

Second: it is worth noting that the process took place at different historical times. The approval took place in the cycle of popular front governments of the Workers' Party (PT), which represented contradictory advances in public educational policies; while the censorship and recollection of the text takes place in the post-coup period against the 
elected government of Dilma Rousseff. Period of advancement of conservative and reactionary ideas, such as the Schools without a Party Movement and the fabrication of the so-called "gender ideology".

Third, the core issue is that the work of art in the classroom is subordinated to the immanent process of education. Returning to the epigraph of this text, literature is not meant to teach, but reflection on literature teaches. Thus, the work of art, in the world, having a pedagogical character, transforms man, modifies him, teaches him; in the classroom, the mediation of the teacher must educate the students' aesthetic senses so that they are prepared for quality aesthetic experiences. Even children's literature must have quality, it must have form and content for this learning: it is not the case of "Eredegalda's sad story".

It is worth mentioning that the removal of the books from schools is considered a mistake, given that it was configured as an act of censorship based on superficial moralistic analyzes. At the same time, more substantial preparation would be needed so that teachers could develop quality work in the use of this work, since training in the use of PNAIC material is still deficient, as well as the strong criticisms of the literacy methodology that underlays it.

The attempt to overcome this debate seems to have been achieved, since the bases were laid for an analysis beyond the current positions and with a clear theoretical basis about works of art. Such analysis allows the statement that the works chosen for the classroom must be quality works, produced as literary works, not ordered or that respond to the needs of the PNAIC. Literature teaching should be done with works that allow such nomenclature so that children have pedagogical experiences that form their aesthetic senses and allow aesthetic experiences in the world outside the classroom.

Perhaps it is worth saying that the role of teachers in the various arts, including literature, is to provide conditions for art to play its role. This cannot be gauged numerically. Sometimes, not even witnessed. 


\section{References}

ALBUQUERQUE, M. Autor de livro atribui polêmica à falta de capacitação de professores. Gazeta Online, Vitória, 2 jun. 2017b. Available at:

https://www.gazetaonline.com.br/noticias/cidades/2017/06/autor-de-livro-atribui-polemicaa-falta-de-capacitacao-de-professores-1014062096.html. Access on: Apr. 20, 2020.

ALBUQUERQUE, M. Livro infantil que sugere casamento entre pai e filha é retirado de escolas no ES. G1 Espírito Santo - TV Gazeta, Vitória, jun. 2017. Available at: https://g1.globo.com/espirito-santo/noticia/livro-infantil-que-sugere-casamento-entre-paie-filha-e-retirado-de-escolas-no-es.ghtml. Access on: Jan. 29, 2018.

BRANT, J. M. Enquanto o sono não vem. Rio de Janeiro: JPA, 2013.

BRASIL. Portal Brasil, com informações da Secretaria de Direitos Humanos. 2017. Available at: http://www.brasil.gov.br/cidadania-e-justica/2017/05/dia-nacional-contraabuso-sexual-de-criancas-e-jovens-e-celebrado-nesta-quinta-18. Access on: Apr. 20, 2020.

CEALE - Centro de Alfabetização, Leitura e Escrita. Nota técnica sobre o livro "Enquanto o sono não vem". Pampulha: UFMG, 2017.

DUARTE, N. Os conteúdos escolares e a ressureição dos mortos: contribuição à teoria histórico-crítica do currículo. Campinas: Autores Associados, 2016.

FERREIRA, P. "Demonizar um conto é consequência de nossa crise moral", diz autor de livro recolhido pelo MEC. G1 O Globo, Rio de Janeiro, 8 jun. 2017. Available at: https://oglobo.globo.com/sociedade/educacao/demonizar-um-conto-consequencia-denossa-crise-moral-diz-autor-de-livro-recolhido-pelo-mec-21453077. Access on: Feb. 20, 2018.

FONSECA, A.; COLARES, A.; DA COSTA, S. Educação infantil: história, formação e desafios. Educação \& Formação, Fortaleza, v. 4, n. 12, p. 82-103, 2019. Available at: https://revistas.uece.br/index.php/redufor/article/view/1270/1305. Access on: Feb. 20, 2020.

JAKOBSON, R. Do realismo na arte. In: TODOROV, T. (Org.). Textos dos formalistas russos. São Paulo: Unesp, 2013. p. 109-122.

LUKÁCS, G. As bases ontológicas do pensamento e da atividade do homem. In: NOGUEIRA, M. A. et al. (Org.). Temas de Ciências Humanas. São Paulo: Ciências Humanas, 1978. p. 1-21.

LUKÁCS, G. Estética 1: la peculiaridad de lo estético. Barcelona: Grijaldo, 1982a. v. 1.

LUKÁCS, G. Estética 2: la peculiaridad de lo estético. Barcelona: Grijaldo, 1982b. v. 2. 
LUKÁCS, G. Friedrich Engels, teórico e crítico da literatura. In: LUKÁCS, G. Marxismo e teoria da literatura. 2. ed. São Paulo: Expressão Popular, 2010. p. 51-103.

LUKÁCS, G. O romance como epopeia burguesa. In: LUKÁCS, G. Arte e sociedade: escritos estéticos 1932-1967. 2. ed. Rio de Janeiro: UFRJ, 2011. p. 193-243.

MEC - Ministério da Educação. Com base em parecer técnico, MEC recolhe das escolas o livro Enquanto o sono não vem. Assessoria de Comunicação Social. Brasília, DF, 8 jun. 2017. Available at: http://portal.mec.gov.br/component/content/article?id=50011:mecrecolhe-das-escolas-o-livro-enquanto-o-sono-nao-vem. Access on: Jan. 29, 2018.

MORORÓ, L. A influência da formação continuada na prática docente. Educação \& Formação, Fortaleza, v. 2, n. 4, p. 36-51, 2017. Available at:

https://revistas.uece.br/index.php/redufor/article/view/122/105. Access on: Apr. 20, 2020.

PERRONE-MOISÉS, L. O ensino da literatura. In: PERRONE-MOISÉS, L. Mutações da literatura no século XXI. São Paulo: Companhia das Letras, 2016. p. 70-82.

SAVIANI, D. Pedagogia histórico-crítica: primeiras aproximações. 10. ed. Campinas: Autores Associados, 2008.

XEREZ, A. S.; COSTA, F. J.; SANTOS, J. D. Educação profissional integrada ao nível médio no Ceará: reformas e contradições. Educação \& Formação, Fortaleza, v. 2, n. 4, p. 204-223, 2017. Available at:

https://revistas.uece.br/index.php/redufor/article/view/130/115. Access on: Apr. 20, 2020.

\footnotetext{
Karla Raphaella Costa Pereira, Centro Universitário Uninassau (Uninassau), Department of Education, Pedagogy Course

i (iDhttp://orcid.org/0000-0001-7507-4627

$\mathrm{PhD}$ and master in Education from the State University of Ceará (UECE), in the line Marxism and Education of the Educator, and graduated in Letters-Portuguese / Literatures from the Federal University of Ceará (UFC) and in Pedagogy from UECE. Coordinator of the Research Group Ontology of Social Being, History, Education and Human Emancipation (GPOSSHE) at UECE.

Authorship contribution: Project management, formal analysis, conceptualization, writing of the essay, research and methodology.

Lattes: http://lattes.cnpq.br/6592056073051492

E-mail: karla_raphaella@hotmail.com
}

\footnotetext{
Frederico Jorge Ferreira Costa, State University of Ceará (UECE), Faculty of Education of Itapipoca, Pedagogy Course

ii Dhttp://orcid.org/0000-0002-8357-4557

Post-Doctor in Philosophy, Doctor and Master in Education and graduated in Law. Professor at the State University of Ceará (UECE), of the Graduate Program in Education (PPGE). Coordinator of the Research Group Ontology of Social Being, History, Education and Human Emancipation (GPOSSHE) at UECE.

Authorship contribution: Review, editing and supervision writing.

Lattes: http://lattes.cnpq.br/7944751664196175

E-mail: frederico.costa@uece.br
}

Educação \& Formação, Fortaleza, v. 5, n. 3, e2996, set./dez. 2020

DOI: https://doi.org/10.25053/redufor.v5i15set/dez.2996

https://revistas.uece.br/index.php/redufor/index 
Ana Paula Sancho Diogo, Prefeitura Fortaleza City Hall, Municipal Education Secretariat

iii@ Dhttp://orcid.org/0000-0001-9654-363X

Master in Education from the State University of Ceará (UECE), in the line Marxism and Educator Training, specialist in Applied Linguistics in Portuguese Language from Faculdade Sete de Setembro (FA7) and in Teaching in the Initial Series of Elementary School I from UECE and graduated in Pedagogy from the Federal University of Ceará (UFC). Teacher of the municipal education network of Fortaleza.

Authorship contribution: Writing of the essay and preparing the formal analysis.

Lattes: http://lattes.cnpq.br/3221880371802043

E-mail: anapaulasancho@yahoo.com.br

\section{How to cite this article (ABNT):}

PEREIRA, Karla Raphaella Costa; COSTA, Frederico Jorge Ferreira; SANCHO DIOGO, Ana Paula. Contrapositions between aesthetics and art teaching: the case of "Eredegalda's sad story". Educ. Form., Fortaleza, v. 5, n. 3, p. 1-22, 2020. Available at: https://revistas.uece.br/index.php/redufor/article/view/2996.

Responsible publisher: Lia Machado Fiuza Fialho Ad hoc experts: Karla Silva and Cristine Brandenburg

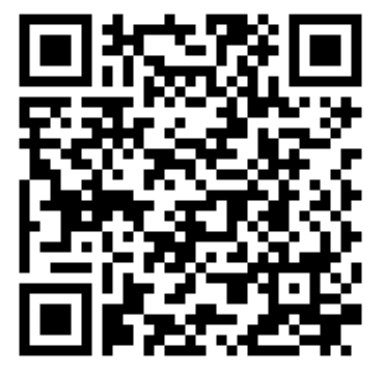

Received on April 14 $4^{\text {th }}, 2020$.

Accepted on May $5^{\text {th }}, 2020$.

Published on April 15 ${ }^{\text {th }}, 2020$. 